\title{
Endothelin Receptor Subtype B Mediates Synthesis of Nitric Oxide by Cultured Bovine Endothelial Cells
}

\author{
Yukio Hirata, Toshiaki Emori, Satoru Eguchi, Kazuo Kanno, Taihei Imai, Kazuki Ohta, and Fumiaki Marumo \\ Endocrine-Hypertension Division, Department of Medicine II, Tokyo Medical and Dental University, Tokyo 113, Japan
}

\begin{abstract}
Endothelins (ET) produce endothelium-dependent vasodilation through nitric oxide (NO) synthesis. The present study was designed to elucidate the cellular mechanism by which ET induces synthesis and release of endothelium-derived NO by cultured bovine endothelial cells (EC). Binding studies revealed that bovine $\mathrm{EC}$ membrane had the binding sites of a novel agonist (BQ3020) for non-isopeptide-selective receptor subtype $\left(\mathbf{E T}_{\mathrm{B}}\right)$. Affinity labeling studies showed a major labeled band with the apparent molecular mass of $50 \mathrm{kD}$. Northern blot analysis demonstrated the expression of mRNA for $\mathrm{ET}_{\mathrm{B}}$ receptor. $\mathrm{BQ3020}$ rapidly and dose dependently induced formation of inositol-1,4,5-triphosphate and increased intracellular $\mathrm{Ca}^{2+}$ concentrations in fura-2-loaded cells. Concomitantly, BQ3020 dose dependently stimulated production of both nitrate/nitrite (NOx) and cyclic GMP; a highly significant correlation existed between NOx and cGMP production. The stimulatory effect on NOx and cGMP production by ET $_{B}$ agonist was inhibited by NO synthase inhibitor monomethyl-Larginine; this effect was reversed by coaddition of $L$-arginine, but not D-arginine. NOx and CGMP production stimulated by BQ3020 was inhibited by pretreatment with pertussis toxin. ET $_{B}$ agonist-induced NOx production was blocked by a calmodulin inhibitor and an intracellular $\mathrm{Ca}^{2+}$ chelator, but not by an extracellular $\mathrm{Ca}^{2+}$ chelator or a $\mathrm{Ca}^{2+}$ channel blocker. These data suggest that endothelins stimulate $\mathbf{E T}_{\mathrm{B}}$ receptor-mediated phosphoinositide breakdown via pertussis toxin-sensitive Gprotein(s), which triggers release of intracellular $\mathrm{Ca}^{2+}$, thereby activating $\mathrm{Ca}^{2+}$ /calmodulin-dependent $\mathrm{NO}$ synthase in EC. (J. Clin. Invest. 1993. 91:1367-1373.) Key words: endothelin • receptor subtype $\mathrm{B} \cdot$ nitric oxide $\bullet \mathrm{Ca}^{2+} /$ calmodulin • endothelial cell
\end{abstract}

\section{Introduction}

Endothelin-1 (ET-1 $)^{1}$ is a potent endothelium-derived vasoconstrictor peptide originally isolated from culture media of porcine vascular endothelial cells (EC) (1). Subsequent human genomic cDNA cloning revealed three distinct ET isopeptides, designated ET-1, ET-2 and ET-3(2). Compared with the equipotent vasoconstrictor/pressor activities of ET-1 and ET2, ET-3 has less vasoconstrictor/pressor activity but the most potent initial depressor response (2), suggesting the existence of receptor subtypes. Recently, cDNA cloning of ET receptors

Address correspondence to Yukio Hirata, M.D., Endocrine-Hypertension Division, Department of Medicine II, Tokyo Medical and Dental University, Yushima 1-5-45, Bunkyo-ku, Tokyo 113, Japan.

Received for publication 1 June 1992 and in revised form 4 November 1992.

J. Clin. Invest.

(c) The American Society for Clinical Investigation, Inc.

0021-9738/93/04/1367/07 \$2.00

Volume 91, April 1993, 1367-1373 from bovine and rat lung has revealed at least two distinct subtypes $(3,4)$ : one selective for ET-1 and ET-2 $\left(\mathrm{ET}_{\mathrm{A}}\right)$ and the other non-isopeptide-selective $\left(\mathrm{ET}_{\mathrm{B}}\right)$. Both receptor subtypes comprise seven transmembrane domains common to the Gprotein-coupled receptors. It has been suggested that vascular smooth muscle has $\mathrm{ET}_{\mathrm{A}}$ receptors that mediate contraction, while vascular $\mathrm{EC}$ has $\mathrm{ET}_{\mathrm{B}}$ receptors that may be involved in the vasodilation $(3,4)$. Very recently, several agonists selective for $\mathrm{ET}_{\mathrm{B}}$ receptors have been developed (5). One of these, BQ3020, a linear ET analog ( $N$-acetyl-Leu-Met-Asp-Lys-GluAla-Val-Tyr-Phe-Ala-His-Leu-Asp-Ile-Ile-Trp), is highly selective for the $\mathrm{ET}_{\mathrm{B}}$ receptors (6); $\mathrm{BQ} 3020$ binds to the $\mathrm{ET}_{\mathrm{B}}$ receptors several thousands times more selectively than to the $\mathrm{ET}_{\mathrm{A}}$ receptors.

Endothelium-derived relaxing factor (EDRF) or nitric oxide $(\mathrm{NO})(7,8)$ is a potent vasodilator with anti-platelet aggregation property produced by a variety of cells including ECs, vascular smooth muscle, macrophages, and neuronal cells (9). The formation of $\mathrm{NO}$ is catalyzed from $\mathrm{L}$-arginine by a NADPH-dependent dioxygenase, termed NO synthase (NOS). There exist at least two distinct isoforms of NOS (9); one is a constitutive, $\mathrm{Ca}^{2+} /$ calmodulin-dependent enzyme present mainly in ECs and brain, while the other is an inducible, $\mathrm{Ca}^{2+} /$ calmodulin-independent enzyme activated by cytokines that is found predominantly in macrophages and vascular smooth muscle cells.

It has been shown that ET-3 is a vasodilator rather than a vasoconstrictor in the isolated perfused rat mesentery via production and release of EDRF/NO (10). We have recently shown that ET-3-induced vasodilation is ascribed mainly to EDRF/NO in isolated porcine pulmonary artery in vitro (11). In cultured bovine ECs, we have demonstrated that ET-3, but not ET-1, stimulates receptor-mediated phosphoinositide breakdown, which increases cytosolic free $\mathrm{Ca}^{2+}$ concentrations $\left(\left[\mathrm{Ca}^{2+}\right]_{\mathrm{i}}\right)(12)$ and activates soluble guanylate cyclase, possibly by the generation of EDRF/NO (13). However, the cellular mechanism by which ET stimulates the synthesis and release of EDRF/NO remains largely unknown. In the present study, we have attempted to ascertain whether vascular ECs predominantly express $E T_{B}$ receptors using receptor binding study with a novel $\mathrm{ET}_{\mathrm{B}}$ receptor agonist and Northern blot analysis, and

1. Abbreviations used in this paper: BAPTA, $N, N, N^{\prime}, N^{\prime}$-tetraacetic acid; $\left[\mathrm{Ca}^{2+}\right]_{\mathrm{i}}$, cytosolic free $\mathrm{Ca}^{2+}$ concentration; cNOS, $\mathrm{Ca}^{2+} /$ calmodulin-dependent constitutive enzyme; DSS, disuccinimidyl suberate; EC, endothelial cell; $\mathrm{EC}_{50}$, half maximal stimulation; $\mathrm{EDRF}$, endotheliumderived relaxation factor; $\mathrm{ET}$, endothelin; $\mathrm{ET}_{\mathrm{A}}$, ET receptor selective

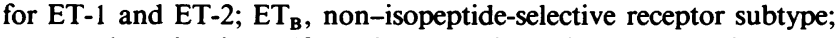
H-7, 1-5-isoquinolinylsulfonyl-2-methylpiperazine; IBMX, 3-isobutyl1-methylxanthine; iNOS, $\mathrm{Ca}^{2+} /$ calmodulin-independent cytokine-inducible enzyme; $\mathrm{IP}_{3}$, inositol-1,4,5-triphosphate; LNMMA, $N^{\mathrm{G}}$-monomethyl-L-arginine; NO, nitric oxide; NOS, nitric oxide synthase; NOx, nitrite/nitrate; PTX, pertussis toxin; W-5, $N$-(6-aminohexyl)-1-naphthalene-sulfonamide; W-7, $N$-(6-aminohexyl)-6-chloro-1-naphthalenesulfonamide. 
to elucidate the intracellular mechanism(s) responsible for NOS activation using an $\mathrm{ET}_{\mathrm{B}}$ receptor agonist in cultured bovine ECs.

\section{Methods}

Drugs. Synthetic BQ3020 (10) was generously provided by Dr. M. Ihara and Dr. M. Yano, Tsukuba Research Institute, Banyu Pharmaceutical Co., Ltd. (Tsukuba, Japan). ET-1, ET-3, leupeptin, and pepstatin D were purchased from Peptide Institute (Osaka, Japan); $N^{\mathrm{G}}$ monomethyl-L-arginine (LNMMA) and 3-isobutyl-1-methylxanthine (IBMX) from Calbiochem Corp. (La Jolla, CA); EDTA, EGTA, 1,2bis(2-aminophenoxy)ethane $N, N, N^{\prime}, N^{\prime}$-tetraacetic acid (BAPTA), $N$-(6-aminohexyl)-1-naphthalene-sulfonamide (W-5), $N$-(6-aminohexyl)-6-chloro-1-naphthalenesulfonamide (W-7), 1-5-isoquinolinylsulfonyl 2-methylpiperazine (H-7), PMSF, disuccinimidyl suberate (DSS), and D- and L-arginine from Sigma Chemical Co. (St. Louis, MO); nicardipine from Yamanouchi Pharmaceutical Co., Ltd. (Tokyo, Japan); pertussis toxin from Kaken Chemical (Tokyo, Japan); methylene blue from Schmidt GmbH (Stuttgart-Unterturkeim, Germany); and fura-2 acetoxymethyl ester from Dojin Chemical (Kumamoto, Japan).

Cell culture and incubation. ECs from bovine carotid artery were prepared and cultured in DME containing 10\% FCS and antibiotics $(100 \mathrm{U} / \mathrm{ml}$ penicillin, $100 \mu \mathrm{g} / \mathrm{ml}$ streptomycin $)$ at $37^{\circ} \mathrm{C}$ in a humidified atmosphere of $95 \%$ air and $5 \% \mathrm{CO}_{2}(5,6)$. The cells were identified as ECs by the contact-inhibited monolayer growth with a "cobblestone" appearance and the presence of Factor VIII antigen detected immunocytochemically. After serial subculture with $0.05 \%$ trypsin and $0.02 \%$ EDTA, ECs harvested between the 8th and 12th passage were used in the experiments. Confluent cells were washed with HBSS that was replaced with fresh HBSS unless otherwise stated.

Binding study. Membranes from ECs were prepared by the same method as previously reported (14). Briefly, bovine ECs and rat cerebellum were homogenized by a Polytron homogenizer (Kinematica AG Littau, Switzerland) in $20 \mathrm{mM}$ phosphate buffer ( $130 \mathrm{mM} \mathrm{NaCl}, 1$ mM EDTA, $0.2 \mathrm{mM}$ PMSF, $10 \mu \mathrm{g} / \mathrm{ml}$ pepstatin, $10 \mu \mathrm{g} / \mathrm{ml}$ leupeptin), $\mathrm{pH} 7.5$; then the mixture was washed, centrifuged, and resuspended in the same buffer. The membrane suspension (15-30 $\mu \mathrm{g}$ protein) was usually incubated with $25 \mathrm{pM}\left[{ }^{125} \mathrm{I}\right] \mathrm{BQ} 3020$ (specific activity 2,000 $\mathrm{Ci} / \mathrm{mmol}$ ) (Amersham Japan, Tokyo, Japan) in the presence or absence of unlabeled peptides at $30^{\circ} \mathrm{C}$ for $30 \mathrm{~min}$. After incubation, free radioactive ligand was removed by centrifugation. Radioactivity was measured with gamma counter (ARC-300; Aloca, Tokyo, Japan). Specific binding was determined by subtracting nonspecific binding in the presence of excess $\left(10^{-6} \mathrm{M}\right)$ unlabeled $\mathrm{BQ} 3020$ from total binding.

Affinity labeling. Affinity labeling of $\left[{ }^{125} \mathrm{I}\right] \mathrm{BQ} 3020$ to the EC membrane was performed as described previously (14). Briefly, the membrane suspension ( $10 \mu \mathrm{g}$ protein) was incubated with $750 \mathrm{pM}\left[{ }^{125} \mathrm{I}\right]-$ $\mathrm{BQ} 3020$ at $30^{\circ} \mathrm{C}$ for $30 \mathrm{~min}$ in the presence or absence of excess amounts $\left(10^{-6} \mathrm{M}\right)$ of unlabeled peptides, and DSS was added to a final concentration of $1 \mathrm{mM}$. The mixture was then incubated for $20 \mathrm{~min}$ at $25^{\circ} \mathrm{C}$, followed by the addition of $2 \mathrm{M}$ ammonium acetate to stop the reaction. The reaction mixture was subjected to SDS-PAGE in the presence of 5\% 2-mercaptoethanol according to the method of Laemmli (15). After electrophoresis, the gels were dried and exposed to film (X-Omat AR; Kodak, Rochester, NY) at $-70^{\circ} \mathrm{C}$ for $5 \mathrm{~d}$.

Northern blot analysis. RNA was extracted from bovine ECs by the acid guanidinium thiocyanate-phenol-chloroform method (16). Briefly, ECs were homogenized in $10 \mathrm{ml}$ guanidinium solution (4 M guanidinium thiocyanate, $25 \mathrm{mM}$ sodium citrate, $0.5 \%$ sarcosyl, and 1\% 2-mercaptoethanol) using a Polytron homogenizer and $1 \mathrm{ml} 2 \mathrm{M}$ sodium acetate ( $\mathrm{pH} \mathrm{4}$ ), $10 \mathrm{ml}$ water-saturated phenol, and $2 \mathrm{ml}$ chloroform-isoamyl alcohol mixture (49:1) were added with through mixing and vortexing; the solution was cooled on ice for $15 \mathrm{~min}$. After centrifugation at $1,000 \mathrm{~g}$ for $20 \mathrm{~min}$, an aqueous phase containing RNA was transferred and precipitated with isopropyl alcohol at $-20^{\circ} \mathrm{C}$ for 20 min. RNA was pelleted by centrifugation, washed with $70 \%$ ethanol, dissolved in diethylpyrocarbonate-treated water, and subjected to poly $(\mathrm{A})^{+}$RNA selection. Poly $(\mathrm{A})^{+}$RNA $(10 \mu \mathrm{g})$ was fractionated by formaldehyde $/ 1.1 \%$ agarose gel electrophoresis and transferred to a nylon membrane (MagnaGraph; Micron Separations Inc., Westboro, MA). Probe for bovine $\mathrm{ET}_{\mathrm{B}}$ receptor cDNAs (17) was labeled with $\left[{ }^{32} \mathrm{P}\right]-$ dCTP (Amersham International, Amersham, UK) by the randomprimed method, and incubated at $42^{\circ} \mathrm{C}$ for $16 \mathrm{~h}$ with the membranes in a hybridization buffer containing $1 \mathrm{M} \mathrm{NaCl} / 50 \%$ (vol/vol) formamide, $1 \%$ SDS, and $250 \mu \mathrm{g} / \mathrm{ml}$ salmon sperm DNA. The membranes were washed with $0.3 \mathrm{M} \mathrm{NaCl}, 30 \mathrm{mM}$ sodium citrate, and $1 \% \mathrm{SDS}$ at $60^{\circ} \mathrm{C}$, and they were autoradiographed on film (X-Omat AR; Rochester) at $-80^{\circ} \mathrm{C}$ for $16 \mathrm{~h}$.

Determination of nitrite/nitrate (NOx). Confluent ECs were usually incubated in Hanks' medium without phenol red at $37^{\circ} \mathrm{C}$ for 1 min unless otherwise specified. Medium was removed and NOx concentration was determined by an autoanalyzer (TCI-NOX 1000; Tokyo Kasei Kogyo Co., Ltd., Tokyo, Japan) as recently described (18). In brief, sample premixed with the carrier solution $(0.07 \%$ EDTA, $0.03 \% \mathrm{NH}_{4} \mathrm{Cl}$ ) was passed through a copperized cadmium reduction column, where $\mathrm{NO}_{3}^{-}$was reduced to $\mathrm{NO}_{2}^{-}$, which reacts with Griess reagent (one part $1 \%$ sulfonamide and one part $0.1 \% N$-1-naphthylethylenediamine dihydrochloride $/ 5 \% \mathrm{HCl}$ ) to form a purple azo dye (19). Absorbence at $540 \mathrm{~nm}$ was detected by a flow-through visible spectrophotometer (model S/3250; Soma-Kogaku Co., Ltd., Tokyo, Japan ) connected to a strip chart recorder. The limit of detection of $\mathrm{NO}_{2}^{-}$was $0.2 \mu \mathrm{M}$ ( $99 \%$ confidence ) and intraassay and interassay coefficients of variation were $1.6 \%$ and $0.7 \%$, respectively.

Determination of inositol-1,4,5-triphosphate $\left(I P_{3}\right)$. For measurement of $\mathrm{IP}_{3}$, confluent ECs were incubated at $37^{\circ} \mathrm{C}$ in HBSS containing $10 \mathrm{mM} \mathrm{LiCl}$ as reported $(12,13)$. Incubation was terminated by the rapid removal of medium and the addition of ice-cold 15\% TCA and the cells were placed on ice for $30 \mathrm{~min}$. The TCA extract was washed with ethylether and neutralized with $1 \mathrm{~N}$ sodium acetate. $\mathrm{IP}_{3}$ levels were determined with an $\mathrm{IP}_{3}$ assay kit (New England Nuclear, Boston, MA).

Determination of intracellular cyclic guanosine monophosphate (cGMP). For measurement of cGMP, confluent cells were incubated at $37^{\circ} \mathrm{C}$ for $10 \mathrm{~min}$ in HBSS containing $0.5 \mathrm{mM}$ IBMX as described previously (13). After extraction with 6\% TCA, the concentration of intracellular CGMP was determined with a cGMP RIA kit (New England Nuclear).

Measurement of cytosolic free $\mathrm{Ca}^{2+}$ concentration $\left(\left[\mathrm{Ca}^{2+}\right]_{i}\right)$. Measurement of $\left[\mathrm{Ca}^{2+}\right]_{i}$ was measured by the $\mathrm{Ca}^{2+}$-fura- 2 fluorescence method as described previously (20). After incubation in serum-free DME for $24 \mathrm{~h}$, ECs were trypsinized and incubated with $4 \mu \mathrm{M}$ fura-2 acetoxymethyl ester at $37^{\circ} \mathrm{C}$ for $20 \mathrm{~min}$ in buffered physiological salt solution, essentially as reported previously (20). The $\mathrm{Ca}^{2+}$-fura-2 fluorescence of the suspended cells $\left(\sim 2 \times 10^{6} \mathrm{cells} / \mathrm{ml}\right)$ was measured by a spectrofluorometer (CAF-100; JASCO Co., Ltd., Tokyo, Japan) using excitation at 340 and $380 \mathrm{~nm}$ and emission at $500 \mathrm{~nm}$. Values of $\left[\mathrm{Ca}^{2+}\right]_{\mathrm{i}}$ were determined according to the method of Grynkiewicz et al (21). $\left[\mathrm{Ca}^{2+}\right]_{\mathrm{i}}$ was calculated by the following equation:

$\left[C a^{2+}\right]_{i}(\mathrm{nM})=K_{\mathrm{d}} \times\left(R-R_{\min }\right) /\left(R_{\max }-R\right) \times \beta$

where $K_{\mathrm{d}}$ is the dissociation constant of fura- 2 for $\mathrm{Ca}^{2+}$ at $37^{\circ} \mathrm{C}(224$ $\mathrm{nM}), R$ represents the ratio of fluorescence of the sample at $340 \mathrm{~nm}$ to that at $380 \mathrm{~nm}, R_{\max }$ and $R_{\min }$ are the ratios of fura- 2 free acid at the same wavelengths in the presence of saturating $\mathrm{Ca}^{2+}$ to those in nominally zero $\mathrm{Ca}^{2+}$ by adding Triton X and EGTA, respectively, and $\beta$ is the ratio of fluorescence of fura-2 at $380 \mathrm{~nm}$ in zero $\mathrm{Ca}^{2+}$ to that in saturating $\mathrm{Ca}^{2+}$.

\section{Results}

Binding study. ${ }^{125} \mathrm{I}$-labeled $\mathrm{BQ} 3020$ specifically bound to bovine ECs and rat cerebellar membranes as a function of time; the maximal binding at $30^{\circ} \mathrm{C}$ was obtained after $30 \mathrm{~min}$, and 

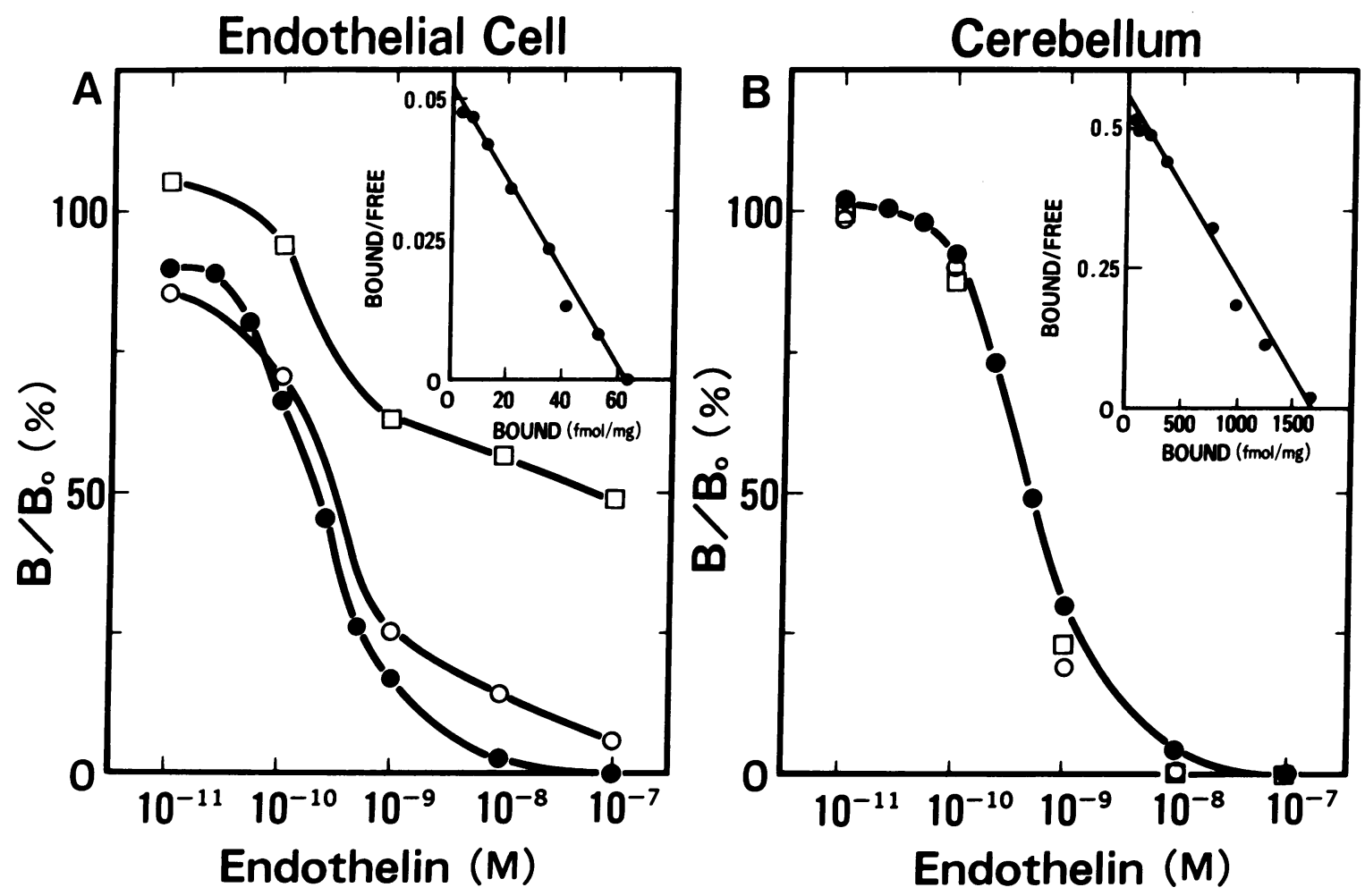

Figure 1. Competitive binding of $\left[{ }^{125} \mathrm{I}\right] \mathrm{ET}_{\mathrm{B}}$ agonist $(\mathrm{BQ} 3020)$ to membranes of cultured bovine endothelial cells and rat cerebellum. Membranes (15-30 $\mu \mathrm{g}$ protein) were incubated with $\left[{ }^{125} \mathrm{I}\right] \mathrm{BQ} 3020$ at $37^{\circ} \mathrm{C}$ for $30 \mathrm{~min}$ in the presence or absence of unlabeled ET-1 (ם), ET-3 (O), and $\mathrm{BQ} 3020(\bullet)$. Each point shows the mean of triplicate samples. (Inset) Scatchard plot of BQ3020 binding.

the nonspecific binding was $<10 \%$ of the total binding (data not shown). As shown in Fig. $1 \mathrm{~A}$, unlabeled BQ3020 and ET-3 equally displaced radioligand binding to EC membranes, while ET-1 was less potent; the apparent $K_{\mathrm{d}}$ was $2 \times 10^{-10} \mathrm{M}$ and the $B_{\max }$ was $62 \mathrm{fmol} / \mathrm{mg}$ protein. In contrast, the binding of [ $\left.{ }^{125} \mathrm{I}\right]$ BQ3020 to rat cerebellar membranes was equally inhibited by unlabeled BQ3020, ET-3, and ET-1 (Fig. $1 B$ ); the apparent $K_{\mathrm{d}}$ and $B_{\max }$ were $2 \times 10^{-10} \mathrm{M}$ and $1.6 \mathrm{pmol} / \mathrm{mg}$ protein, respectively.

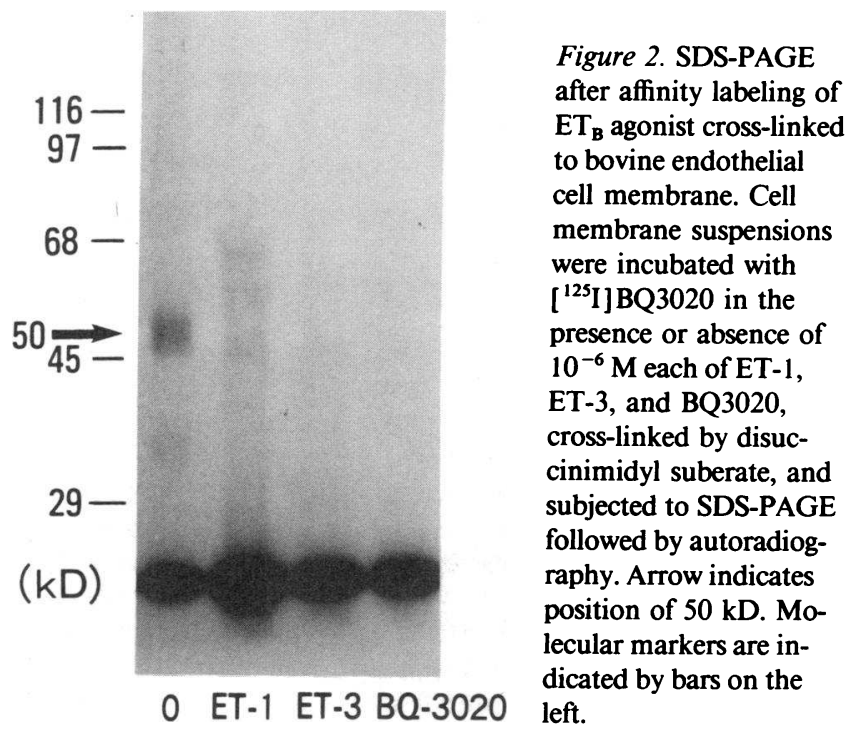

SDS-PAGE after affinity labeling of ${ }^{125} \mathrm{I}$-labeled BQ3020 to EC membranes by bifunctional crosslinker DSS revealed one major labeled band with an apparent molecular mass of $50 \mathrm{kD}$ (Fig. 2); this band was completely abolished by an excess amount $\left(10^{-6} \mathrm{M}\right)$ of unlabeled $\mathrm{BQ} 3020$ and ET-3, but incompletely by ET-1.

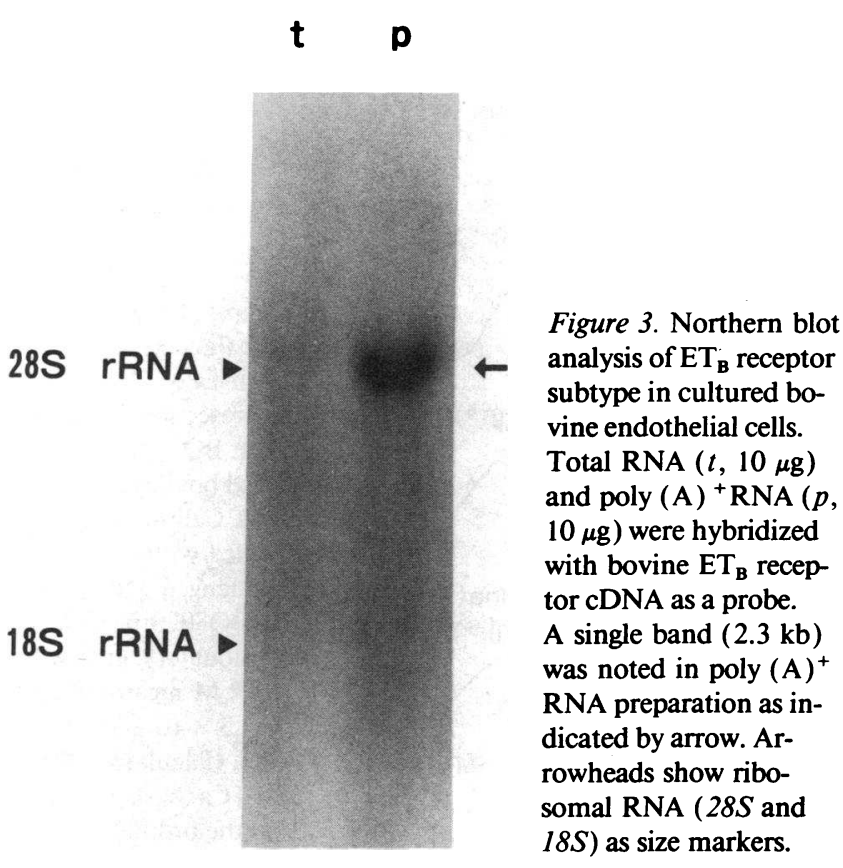




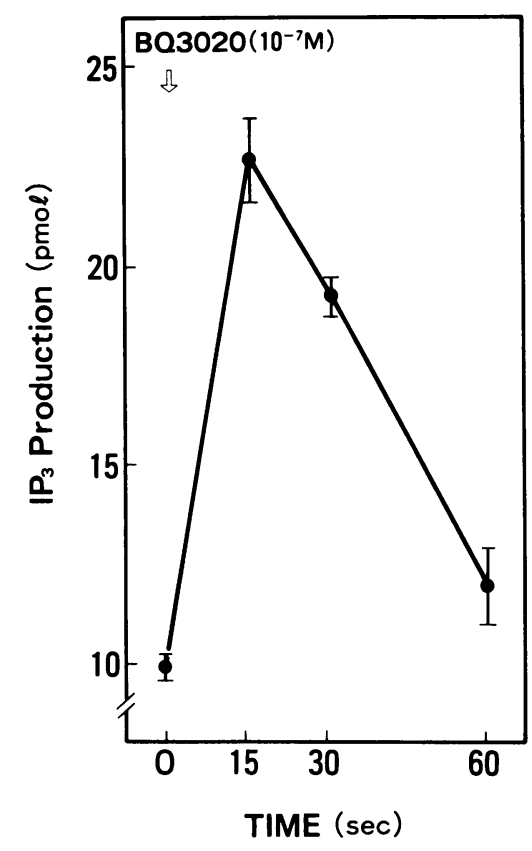

Figure 4. Effect of $\mathrm{ET}_{\mathrm{B}}$ agonist $\mathrm{BQ} 3020$ on $\mathrm{IP}_{3}$ production as a function of time in cultured bovine endothelial cells. After addition of $10^{-7}$ M BQ3020, confluent cells were incubated for indicated times. $\mathrm{IP}_{3}$ generation was determined. Each point with bar shows the mean $\pm \operatorname{SEM}(n=6)$.

Northern blot analysis. Northern blot hybridization of poly (A) ${ }^{+}$RNA from bovine ECs with cloned cDNA for bovine $\mathrm{ET}_{\mathrm{B}}$ receptor as a probe revealed a distinct band $(4.8 \mathrm{~kb})$ corresponding to the size of $\mathrm{ET}_{\mathrm{B}}$ receptor mRNA (Fig. 3).

$I_{3}$ production and $\left[\mathrm{Ca}^{2+}\right]_{i}$ increase by $\mathrm{ET}_{\mathrm{B}}$ agonist. $\mathrm{BQ} 3020$ rapidly stimulated $\mathrm{IP}_{3}$ production, which peaked at 15 $\mathrm{S}$ and then declined almost to basal levels by $1 \mathrm{~min}$ (Fig. 4). BQ3020 also induced an immediate increase in $\left[\mathrm{Ca}^{2+}\right]_{i}$, which peaked at $15 \mathrm{~s}$ and returned to basal levels after $1 \mathrm{~min}$ (Fig. 5); the $\mathrm{ET}_{\mathrm{B}}$ agonist-induced increase in $\left[\mathrm{Ca}^{2+}\right]_{\mathrm{i}}$ was not affected by pretreatment with nicardipine or EGTA. As shown in Fig. 6, BQ3020 similarly stimulated $\mathrm{IP}_{3}$ production and $\left[\mathrm{Ca}^{2+}\right]_{i}$ increase in a dose-dependent fashion $\left(10^{-9}-10^{-7} \mathrm{M}\right)$; the approximate doses of $\mathrm{BQ} 3020$ for half maximal stimulation $\left(\mathrm{EC}_{50}\right)$ and maximal stimulation were $5 \times 10^{-9}$ and $10^{-7} \mathrm{M}$, respectively.

Production of NOx and $c G M P$ by $E T_{B}$ agonist. BQ3020 rapidly stimulated production and release of $\mathrm{NOx}$, which

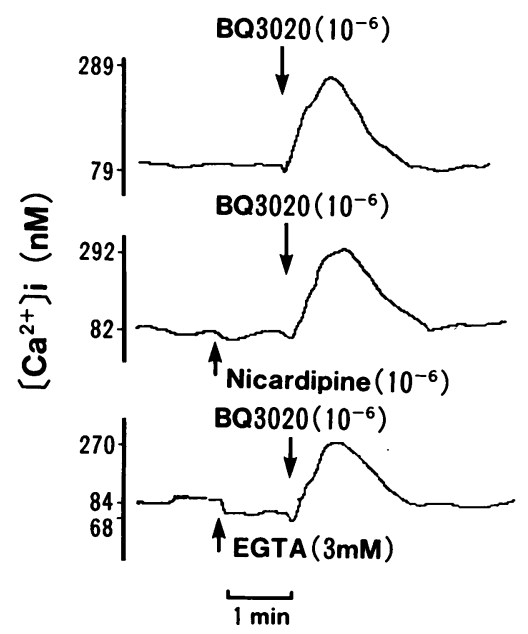

Figure 5. Representative tracings show changes of $\mathrm{Ca}^{2+}$-fura-2 fluorescence by $\mathrm{ET}_{\mathrm{B}}$ agonist BQ3020 in cultured bovine endothelial cells. Cell suspensions loaded with fura-2 were challenged with $10^{-6}$ M BQ3020 pretreated without $(A)$, and with $10^{-6} \mathrm{M}$ nicardipine $(B)$ and $3 \times 10^{-3} \mathrm{M}$ EGTA (C). Calculated values for $\left[\mathrm{Ca}^{2+}\right]_{\mathrm{i}}$ are shown on the ordinates.
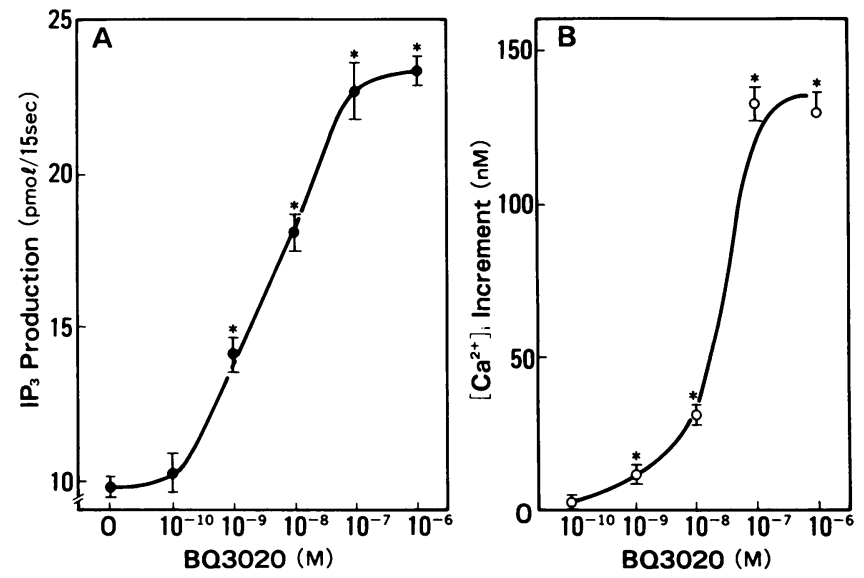

Figure 6. Effect of $\mathrm{ET}_{\mathrm{B}}$ agonist $(\mathrm{BQ} 3020)$ on $\mathrm{IP}_{3}$ production and increase in $\left[\mathrm{Ca}^{2+}\right]_{\mathrm{i}}$ in cultured bovine endothelial cells. $(A)$ Confluent cells were incubated at $37^{\circ} \mathrm{C}$ with various doses $\left(10^{-10}-10^{-6} \mathrm{M}\right)$ of $\mathrm{BQ} 3020$ for $15 \mathrm{~s}$ and $\mathrm{IP}_{3}$ generation was determined. (B) Fura-2loaded cells were incubated with various doses of $\mathrm{BQ} 3020$; agonistinduced increment of $\left[\mathrm{Ca}^{2+}\right]_{\mathrm{i}}$ was calculated from basal levels $(79 \pm 5.9 \mathrm{nM})$. Each point with bar shows the mean \pm SEM $(n=4)$. $* P<0.05$ vs. control.

peaked at $1 \mathrm{~min}$ and lasted for $\geq 20 \mathrm{~min}$, and similarly stimulated cGMP generation, which peaked at 5-10 min in the presence of the phosphodiesterase inhibitor IBMX (data not shown ). As shown in Fig. 7, BQ3020 dose dependently $\left(10^{-9}\right.$ $10^{-7} \mathrm{M}$ ) stimulated production of both NOx and cGMP with almost comparable $\mathrm{EC}_{50}$ value $\left(\sim 2 \times 10^{-8} \mathrm{M}\right)$. There was a highly significant $(P<0.001)$ correlation $(r=0.93)$ between NOx and cGMP production. Methylene blue $\left(10^{-3} \mathrm{M}\right)$, a soluble guanylate cyclase inhibitor, completely blocked BQ3020induced cGMP generation (data not shown).

Arginine as a substrate for NOx production. To ascertain whether $\mathrm{ET}_{\mathbf{B}}$ agonist-induced NOx production is mediated by NOS, the effect of the stereospecific NOS inhibitor, LNMMA, on NOx production was studied. The BQ3020-induced NOx production was completely inhibited by $4 \times 10^{-4} \mathrm{M}$ LNMMA,
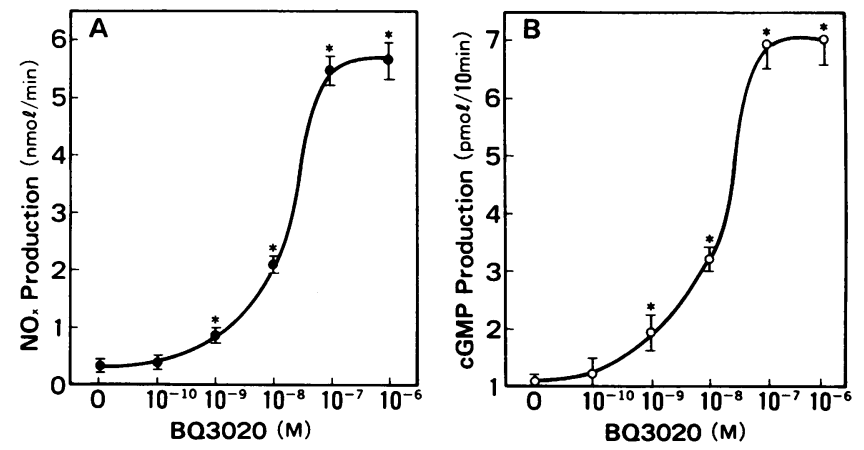

Figure 7. Effect of $\mathrm{ET}_{\mathrm{B}}$ agonist $\mathrm{BQ} 3020$ on production of $\mathrm{NOx}$ and cGMP in cultured bovine endothelial cells. $(A)$ Confluent cells were incubated with or without various doses $\left(10^{-10}-10^{-6} \mathrm{M}\right)$ of BQ3020 at $37^{\circ} \mathrm{C}$ for $1 \mathrm{~min}$ : NOx released into medium was measured. $(B)$ Confluent cells were incubated with or without the same doses of $\mathrm{BQ} 3020$ at $37^{\circ} \mathrm{C}$ for $10 \mathrm{~min}$ in the presence of $0.5 \mathrm{mM}$ methylisobutylxanthine; intracellular cGMP produced was determined. Each point with bar shows the mean $\pm \operatorname{SEM}(n=6)$. ${ }^{*} P<0.05$ vs. control. 


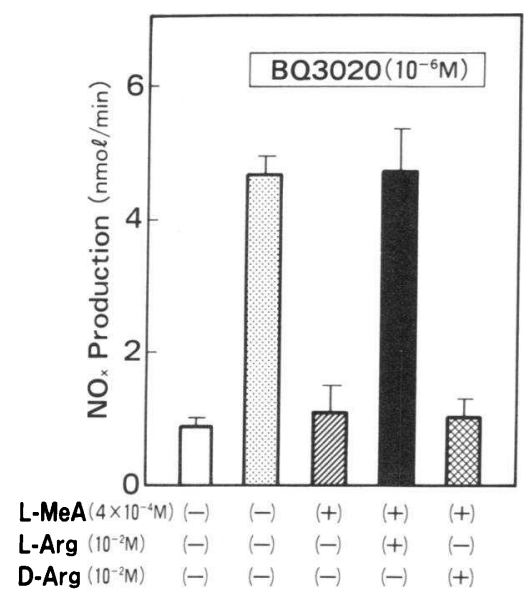

into medium was measured. Each column $\mathrm{Arg}(\mathbf{\square})$, NOx released shows $\operatorname{SEM}(n=6)$.

and this effect was reversed by the simultaneous addition of $10^{-2} \mathrm{M}$ L-arginine, but not by $10^{-2} \mathrm{M}$ D-arginine (Fig. 8).

Involvement of pertussis toxin (PTX)-sensitive G-pro$\operatorname{tein}(s)$. To determine whether PTX-sensitive G-protein(s) is involved in $\mathrm{ET}_{\mathrm{B}}$ receptor-mediated NO synthesis, cultured bovine ECs were pretreated with PTX $(100 \mathrm{ng} / \mathrm{ml})$ for $6 \mathrm{~h}$, and the effect of the $\mathrm{ET}_{\mathrm{B}}$ agonist on NOx and cGMP production was studied (Fig. 9). BQ3020-induced production of both NOx and CGMP was abolished in a similar fashion by pretreatment with PTX, while PTX alone had no effect on the basal production of NOx and CGMP.

Role of $\mathrm{Ca}^{2+} /$ calmodulin system in NOx production. To elucidate whether $\mathrm{ET}_{\mathrm{B}}$ receptor-mediated NOx synthesis requires $\mathrm{Ca}^{2+}$ from an intracellular and/or extracellular source, the effects of an intracellular $\mathrm{Ca}^{2+}$ chelator (BAPTA) and an extracellular $\mathrm{Ca}^{2+}$ chelator (EGTA) on NOx production were studied (Table I). Removal of an intracellular $\mathrm{Ca}^{2+}$ by

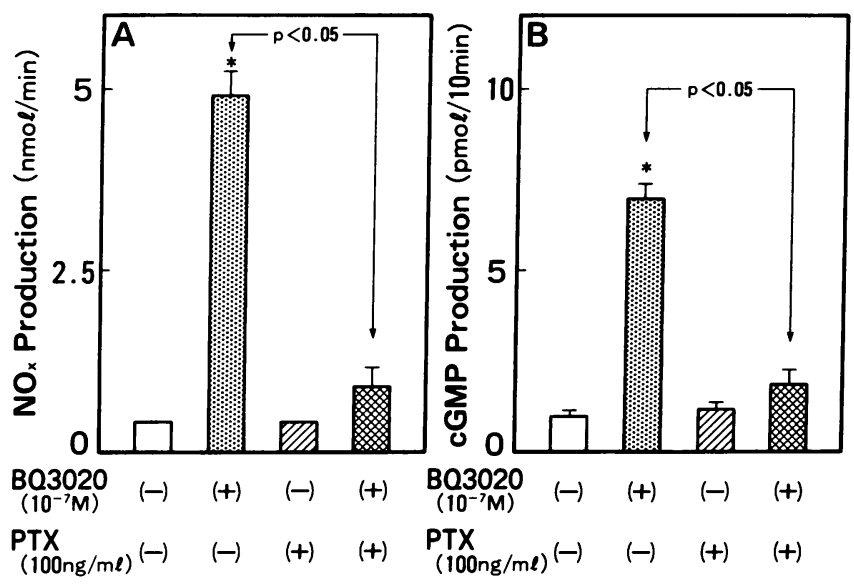

Figure 9. Effect of PTX on $\mathrm{ET}_{\mathrm{B}}$ agonist $\mathrm{BQ} 3020$-induced production of NOx and cGMP in cultured bovine endothelial cells. After pretreatment without $(\square, \square)$ or with $(\square, \square)$ PTX $(100 \mathrm{ng} / \mathrm{ml})$ for $6 \mathrm{~h}$, cells were incubated in the absence ( $\square, \square)$ or the presence $(\square, \square)$ of $10^{-7} \mathrm{M} \mathrm{BQ} 3020$ for measurement of $(A)$ NOx production and $(B)$ cGMP generation, as in Fig. 7. Each column represents the mean; bar shows $\operatorname{SEM}(n=6) .{ }^{*} P<0.05$ vs. control.
Table I. Effects of Various Compounds on $E T_{B}$ Agonist (BQ3020)-induced NOx Production by Cultured Bovine Endothelial Cells

\begin{tabular}{lc}
\hline \multicolumn{1}{c}{ Drugs (concentration) } & NOx production \\
\hline & nmol/min \\
None & $0.90 \pm 0.11$ \\
BQ3020 $\left(10^{-6} \mathrm{M}\right)$ & $4.80 \pm 0.12^{*}$ \\
BQ3020 $\left(10^{-6} \mathrm{M}\right)+\mathrm{BAPTA}\left(3 \times 10^{-3} \mathrm{M}\right)$ & $1.19 \pm 0.09$ \\
BQ3020 $\left(10^{-6} \mathrm{M}\right)+\mathrm{EGTA}\left(3 \times 10^{-3} \mathrm{M}\right)$ & $4.56 \pm 0.19^{*}$ \\
BQ3020 $\left(10^{-6} \mathrm{M}\right)+\mathrm{W}-7\left(5 \times 10^{-5} \mathrm{M}\right)$ & $2.02 \pm 0.17^{*}$ \\
BQ3020 $\left(10^{-6} \mathrm{M}\right)+\mathrm{W}-5\left(5 \times 10^{-5} \mathrm{M}\right)$ & $4.84 \pm 0.22^{*}$ \\
BQ3020 $\left(10^{-6} \mathrm{M}\right)+\mathrm{H}-7\left(10^{-6} \mathrm{M}\right)$ & $5.01 \pm 0.34^{*}$ \\
\hline
\end{tabular}

Confluent bovine endothelial cells $\left(10^{5}\right.$ cells/dish) were incubated at $37^{\circ} \mathrm{C}$ for $1 \mathrm{~min}$ in the absence and presence of $10^{-6} \mathrm{M} \mathrm{BQ} 3020$ alone and in combination with either an intracellular $\mathrm{Ca}^{2+}$ chelator (BAPTA), an extracellular $\mathrm{Ca}^{2+}$ chelator (EGTA), a relatively selective calmodulin inhibitor (W-7), a nonselective calmodulin inhibitor (W-5), and a protein kinase $\mathrm{C}$ inhibitor ( $\mathrm{H}-7)$ in concentrations as indicated. NOx released into medium was measured as described in Methods. Each value is the mean $\pm \operatorname{SEM}(n=6) .{ }^{*} P<0.05$ vs. control.

$3 \times 10^{-3} \mathrm{M}$ BAPTA completely abolished NOx production stimulated by $10^{-6} \mathrm{M}$ BQ3020, whereas removal of extracellular $\mathrm{Ca}^{2+}$ by $3 \times 10^{-3} \mathrm{M}$ EGTA had no effect.

The effects of calmodulin inhibitors and a protein kinase $C$ inhibitor on $\mathrm{ET}_{\mathrm{B}}$ agonist-induced NOx production were also examined (Table I). The BQ3020-induced NOx production was significantly decreased by a relatively selective calmodulin inhibitor (W-7), but not by either a nonselective calmodulin inhibitor (W-5) or a protein kinase C inhibitor (H-7).

\section{Discussion}

Recent $\mathrm{CDNA}$ cloning studies have revealed the existence of at least two subtypes of $E T$ receptors, termed $\mathrm{ET}_{A}$ and $\mathrm{ET}_{B}(3,4)$; $E T_{A}$ receptor shows selective affinity for ET-1, whereas $E_{B}$ receptor shows nonselective affinity for ET isopeptides. It has been suggested that vascular smooth muscle expresses $E_{\mathrm{A}}$ receptors that mediate contraction, while vascular endothelium expresses $\mathrm{ET}_{\mathrm{B}}$ receptors that mediate relaxation, possibly via production of EDRF/NO and prostacyclin $(3,4)$. Recently, several analogs selective for $\mathrm{ET}_{\mathrm{B}}$ receptors have been synthesized (5), among which $\mathrm{BQ} 3020$ has been shown to be the most potent, stable, and selective agonist for $\mathrm{ET}_{\mathrm{B}}$ receptor thus far reported (6); BQ3020 displaces [ ${ }^{125}$ I]ET-1 binding to the $\mathrm{ET}_{\mathrm{B}}$ receptor in the porcine cerebellar membranes with a selectivity 4,700 times greater than that to the $\mathrm{ET}_{\mathrm{A}}$ receptor in vascular smooth muscle. We have confirmed that $\left[{ }^{125} \mathrm{I}\right] \mathrm{BQ} 3020$ binding to rat cerebellar membrane is inhibited equipotently by BQ3020, ET-1, and ET-3 with high affinity similar to that of porcine cerebellar membrane (6).

The present binding study clearly demonstrated the presence of binding sites for $\mathrm{ET}_{\mathrm{B}}$ agonist in cultured bovine ECs with high affinity $\left(K_{\mathrm{D}}-2 \times 10^{-10} \mathrm{M}\right)$ comparable to that of rat cerebellar membranes. In contrast to the complete and equal binding inhibition by ET isopeptides in cerebellar membranes, unlabeled ET-1 failed to displace [ $\left.{ }^{125} \mathrm{I}\right] \mathrm{BQ} 3020$ completely from its binding site in EC membranes. The same apparent 
lack of complete displacement by unlabeled ET-1 has already been shown in [ $\left.{ }^{125} \mathrm{I}\right] \mathrm{ET}-3$ binding to cultured bovine ECs (12) and human ECs (22). Several possible mechanisms may account for the anomalous behavior of ET-1 in cultured ECs. First, this may be caused by differences in the dissociation rates of ET isopeptides. Indeed, it has been reported that the dissociation of $\left[{ }^{125} \mathrm{I}\right] \mathrm{ET}-1$ bound to Swiss 3T3 fibroblasts is much slower than that of [ $\left.{ }^{125} \mathrm{I}\right] \mathrm{ET}-2(23)$. Second, this may be ascribable to downregulation of the $\mathrm{ET}_{\mathrm{B}}$ receptor by endogenous ET1 constitutively secreted by ECs as previously suggested (14). It has recently been shown that pretreatment of cultured human ECs with phosphoramidon, a putative ET-converting enzyme inhibitor, led to an increase in the binding capacity of the $\mathrm{ET}_{\mathbf{B}}$ receptor that interacts equally with ET-1 and ET-3 (24), suggesting upregulation of endothelial $\mathrm{ET}_{\mathrm{B}}$ receptor after blocking processing from big ET-1 to ET-1. We have confirmed these observations in that bovine endothelial $\mathrm{ET}_{\mathbf{B}}$ receptor exhibits equal binding affinity for ET-1 and ET-3 in phosphoramidontreated cells (unpublished observation). Third, there may be another receptor subtype in addition to the $\mathrm{ET}_{\mathrm{A}}$ and $\mathrm{ET}_{\mathrm{B}}$ receptors that prefers ET-3 over ET-1. However, there have been no reports thus far on the isolation of cDNA clones encoding an ET-3 selective receptor $\left(E_{C}\right)(25)$; Southern blot analysis of human genomic DNA using $\mathrm{ET}_{\mathrm{A}}$ and $\mathrm{ET}_{\mathrm{B}}$ receptor cDNA probes revealed only two different genomic DNA fragments even under low stringency conditions (26), suggesting that mammalian genomes contain only two closely related ET receptor genes, probably for the $\mathrm{ET}_{\mathrm{A}}$ and $\mathrm{ET}_{\mathrm{B}}$ receptors. Should a third novel receptor gene exist in mammalian genomes, it has little if any similarity to the two known receptors. Whatever the mechanism involved, our study shows that ET-3 preferentially interacts with $\mathrm{ET}_{\mathrm{B}}$ receptor in cultured bovine ECs.

Affinity labeling experiments to visualize receptor molecules on SDS-PAGE after covalent binding of BQ3020 to EC membranes by a bifunctional cross-linker revealed one major labeled band with the apparent molecular mass of $50 \mathrm{kD}$, whose size appears to be comparable to that of the $\mathrm{ET}_{\mathrm{B}}$ receptor $(4,14,17)$. Northern blot analysis of poly(A) ${ }^{+}$RNA from cultured bovine EC verified the expression of the $\mathrm{ET}_{\mathrm{B}}$ receptor gene in these cells.

In our previous study (12), we showed that ET-3 stimulates receptor-mediated phosphoinositide breakdown, which triggers intracellular $\mathrm{Ca}^{2+}$ mobilization in cultured bovine ECs. Subsequent studies have shown that ET-3 stimulates soluble guanylate cyclase activity, possibly resulting from NO formation in cultured bovine ECs (13). The present study clearly demonstrated that $\mathrm{BQ} 3.020$, a more selective $\mathrm{ET}_{\mathrm{B}}$ agonist than ET-3, rapidly and dose dependently stimulated phosphoinositide breakdown and $\left[\mathrm{Ca}^{2+}\right]_{i}$ increase in cultured bovine ECs. These findings are consistent with our previous observation that ET-3 induces receptor-mediated phosphoinositide breakdown and $\left[\mathrm{Ca}^{2+}\right]_{\mathrm{i}}$ increase in the same cell preparation (12). The coincident times of peak $\mathrm{IP}_{3}$ formation and $\left[\mathrm{Ca}^{2+}\right]_{\mathrm{i}}$ transient elicited by BQ3020 and the failure of the response, either by removal of extracellular $\mathrm{Ca}^{2+}$ with EGTA or by blockade of voltage-dependent $\mathrm{Ca}^{2+}$ channels with nicardipine, strongly suggest that the $\left[\mathrm{Ca}^{2+}\right]_{\mathrm{i}}$ increase derives mainly from $\mathrm{IP}_{3}$-mediated intracellular $\mathrm{Ca}^{2+}$ release rather than $\mathrm{Ca}^{2+}$ influx from an extracellular source.

Furthermore, the present study showed that an $\mathrm{ET}_{\mathrm{B}}$ agonist immediately and dose dependently stimulated NOx and cGMP production in cultured bovine ECs. The highly signifi- cant correlation between NOx production and cGMP generation and the inhibitory effect of methylene blue on cGMP generation in bovine ECs suggest that $\mathrm{ET}_{\mathrm{B}}$ agonist-induced NO production led to the stimulation of soluble guanylate cyclase within the same cells. However, the physiological function(s) of NO-induced cGMP generation in ECs remains unknown.

There appears to be a discrepancy between the apparent $K_{\mathrm{d}}$ for $\mathrm{BQ} 3020$ binding $\left(\sim 2 \times 10^{-10} \mathrm{M}\right)$ and the $\mathrm{EC}_{50}$ values for $\mathrm{IP}_{3}$ formation and $\left[\mathrm{Ca}^{2+}\right]_{\mathrm{i}}$ transient $\left(\sim 5 \times 10^{-9} \mathrm{M}\right)$ and the corresponding values for NOx and cGMP production $(\sim 2$ $\times 10^{-8} \mathrm{M}$ ). Such a discrepancy may be partly accounted for by the use of different incubation conditions (temperature and time) and preparations (cell membranes, dispersed cells, and monolayers). Alternatively, different cellular responses to the $\mathrm{ET}_{\mathrm{B}}$ agonist may be mediated via activation of different subpopulations of $\mathrm{ET}_{\mathrm{B}}$ receptors, although Scatchard analysis of $\mathrm{BQ} 3020$ binding revealed a single class of binding sites in EC membranes. It should be noted that there is also a discrepancy between the binding affinity of $\mathrm{ET}_{\mathrm{A}}$ receptor and ET-1-induced cellular responses, including $\mathrm{IP}_{3}$ formation, $\left[\mathrm{Ca}^{2+}\right]_{\mathrm{i}}$ increase, and contraction in rat glomerular mesangial cells (27).

Both $\mathrm{ET}_{\mathrm{A}}$ and $\mathrm{ET}_{\mathrm{B}}$ receptor subtypes have seven hydrophobic membrane-spanning domains belonging to the superfamily of G-protein-coupled receptors $(3,4,17)$. Several types of Gproteins have been identified in cardiovascular tissues (28). Pertussis toxin induces NAD-dependent ADP ribosylation of the $\alpha$-subunit of several G-proteins ( $\mathrm{Gi}, \mathrm{Go}$, and $\mathrm{Gq}$ ). The present study revealed that pertussis toxin completely blocked $\mathrm{ET}_{\mathrm{B}}$ agonist-induced NOx and CGMP production in bovine ECs. In our previous study (13), pertussis toxin was shown to block phosphoinositide breakdown and the $\left[\mathrm{Ca}^{2+}\right]_{\mathrm{i}}$ increase stimulated by ET-3 in bovine ECs. These data are in contrast to findings with the $\mathrm{ET}_{\mathrm{A}}$ receptor in vascular smooth muscle, which is functionally coupled to phospholipase C-mediated phosphoinositide breakdown via pertussis toxin-insensitive Gproteins (29). Taken together, these observations suggest that the $\mathrm{ET}_{\mathrm{B}}$ receptor in vascular endothelium is functionally coupled to phospholipase $\mathrm{C}$, possibly via pertussis toxin-sensitive G-protein(s) involved in synthesis and/or release of EDRF/NO.

EDRF/NO is produced from L-arginine by NADPH-de-

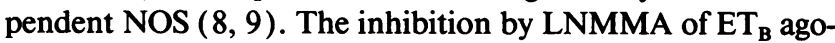
nist-induced NOx production, as well as its reversal by L-arginine, but not by D-arginine, as demonstrated in this study, is consistent with the notion that NOS requires stereoselectivity for the L-enantiomer of arginine as a substrate to generate NO (30). At least two isoforms of NADPH-dependent NOS have been found in a variety of tissues and cells (9). Brain NOS is a constitutive $\mathrm{Ca}^{2+} /$ calmodulin-dependent enzyme (cNOS), the entire structure of which has been elucidated by cDNA cloning of rat brain (31). Macrophage NOS, on the other hand, is $\mathrm{Ca}^{2+}$ /calmodulin-independent cytokine-inducible enzyme (iNOS), of which the entire structure has recently been determined by cDNA cloning of murine macrophages (32). Both isoforms share $50 \%$ sequence homology and comprise binding sites for NADPH, flavin mononucleotide, and flavin adenine dinucleotide. Very recently, a distinct cNOS isoform from bovine ECs has been cloned (33), which shows $50-60 \%$ sequence identity with murine macrophage iNOS and rat brain cNOS isoforms.

The present study clearly showed that $\mathrm{ET}_{\mathrm{B}}$ receptor-mediated NO synthesis in bovine $\mathrm{EC}$ requires $\mathrm{Ca}^{2+}$ and calmodu- 
lin, based on the observations that $\mathrm{BQ} 3020$-induced NOx production is completely blocked by an intracellular $\mathrm{Ca}^{2+}$ chelator (BAPTA), but not by an extracellular $\mathrm{Ca}^{2+}$ chelator (EGTA), and by a relatively selective calmodulin inhibitor (W-7), but not by a less selective calmodulin inhibitor (W-5) or a protein kinase $\mathrm{C}$ inhibitor ( $\mathrm{H}-7)$. It has been suggested that endothelial NOS is constitutive and dependent on $\mathrm{Ca}^{2+} /$ calmodulin (9, 34). In fact, cNOS isoforms from bovine ECs (33) and rat brain (31), but not iNOS from murine macrophages (32), contain binding sites for calmodulin within the molecule. From these findings, we conclude that vascular endothelium contains $\mathrm{cNOS}$ that is activated by a Ca${ }^{2+} /$ calmodulin-dependent pathway resulting from $\mathrm{ET}_{\mathrm{B}}$ receptor-mediated phosphoinositide breakdown and $\mathrm{Ca}^{2+}$ mobilization via pertussis toxin-sensitive G-protein(s).

\section{Acknowledgments}

We thank Dr. M. Yano and Dr. M. Ihara (Banyu Tsukuba Research Institute) for supplying BQ3020 and for their helpful discussion, and Dr. S. Hirose, (Tokyo Institute of Technology) for providing bovine ET $_{B}$ cDNA.

This study was supported in part by Research Grants from the Ministry of Education, Culture and Science of Japan, and a fund from the Uehara Memorial Foundation.

\section{References}

1. Yanagisawa, M., H. Kurihara, S. Kimura, Y. Tomobe, M. Kobayashi, Y Yazaki, K. Goto, and T. Masaki. 1988. A novel potent vasoconstrictor peptide produced by vascular endothelial cells. Nature (Lond.). 332:411-415.

2. Inoue, A., M. Yanagisawa, S. Kimura, Y. Kasuya, T. Miyauchi, K. Goto, and T. Masaki. 1989. The human endothelin family: three structurally and pharmacologically distinct isopeptides predicted by three separate genes. Proc. Natl. Acad. Sci. USA. 86:2863-2867.

3. Arai, H., S. Hori, I. Aramori, H. Ohkubo, and S. Nakanishi. 1990. Cloning and expression of a cDNA encoding an endothelin receptor. Nature (Lond.). 348:730-732.

4. Sakurai, T., M. Yanagisawa, Y. Takuwa, H. Miyazaki, S. Kimura, K. Goto, and T. Masaki. 1990. Cloning of a cDNA encoding a non-isopeptide-selective subtype of the endothelin receptor. Nature (Lond.). 348:732-735.

5. Saeki, T., M. Ihara, T. Fukuroda, M. Yamagiwa, and M. Yano. 1991 [Ala ${ }^{1,3,11,15}$ ] Endothelin-1 analogs with $\mathrm{ET}_{\mathrm{B}}$ agonistic activity. Biochem. Biophys. Res. Commun. 179:286-292.

6. Ihara, M., T. Saeki, T. Fukuroda, S. Kimura, S. Ozaki, A. C. Patel, and M. Yano. 1992. A novel radioligand [ $\left.{ }^{125} \mathrm{I}\right] \mathrm{BQ} 3020$ selective for endothelin $\left(\mathrm{ET}_{\mathrm{B}}\right)$ receptors. Life Sci. 51:PL47-PL52.

7. Furchgott, R. F., and J. V. Zawadzki. 1980. The obligatory role of endothelial cells in the relaxation of arterial smooth muscle by acetylcholine. Nature (Lond.). 288:373-376.

8. Palmer, R. M. J., D. S. Ashton, and S. Moncada. 1988. Vascular endothelial cells synthesize nitric oxide from L-arginine. Nature (Lond.). 333:664-666.

9. Förstermann, U., H. H. H. W. Schmidt, J. S. Pollock, H. Sheng, J. A. Mitchell, T. D. Warner, M. Nakane, and F. Murad. 1991. Isoforms of nitric oxide synthase: characterization and purification from different cell types. Biochem. Pharmacol. 42:1849-1857.

10. Warner, A., G. de Nucci, and J. R. Vane. 1989. Endothelin is a vasodilator in the isolated perfused mesentery of the rat. Eur. J. Pharmacol. 159:325-326.

11. Namiki, A., Y. Hirata, M. Ishikawa, M. Mori, J. Akikawa, and K. Machii. 1992. Endothelin-1 and endothelin-3-induced vaso-relaxation via common generation of endothelium-derived nitric oxide. Life Sci. 50:677-682.

12. Emori, T., Y. Hirata, and F. Marumo. 1990. Specific receptors for endothelin-3 in cultured bovine endothelial cells and its cellular mechanism of action. FEBS (Fed. Eur. Biochem. Soc.) Lett. 263:261-264.
13. Emori, T., Y. Hirata, K. Kanno, K. Ohta, S. Eguchi, T. Imai, M. Shichiri, and F. Marumo. 1991. Endothelin-3 stimulates production of endothelium-derived nitric oxide via phosphoinositide breakdown. Biochem. Biophys. Res. Commun. 174:228-235.

14. Eguchi, S., M. Kozuka, S. Hirose, T. Ito, Y. Hirata, F. Marumo, and H. Hagiwara. 1991. Identification of G-protein-coupled endothelin receptors in cultured bovine endothelial cells. Biochem. Biophys. Res. Commun. 174:13431346.

15. Laemmli, U. K. 1970. Change of structural proteins during the assembly of the head of bacteriophage $T_{4}$. Nature (Lond.). 227:680-685.

16. Chomczynski, P., and N. Sacchi. 1987. Single-step method of RNA isolation by acid guanidinium thiocyante. Anal. Biochem. 162:156-159.

17. Saito, Y., T. Mizumo, M. Itakura, T. Ito, Y. Suzuki, H. Hagiwara, and S. Hirose. 1991. Primary structure of bovine endothelin $\mathrm{ET}_{B}$ receptor and identification of signal peptidase and metal proteinase cleavage sites. J. Biol. Chem 266:23433-23437.

18. Kanno, K., Y. Hirata, T. Emori, K. Ohta, S. Eguchi, T. Imai, and F. Marumo. 1992. L-Arginine infusion induces hypotension and diuresis/natriuresis with concomitant increased urinary excretion of nitrite/nitrate and cyclic GMP. Clin. Exp. Pharmacol. Physiol. 19:619-625.

19. Green, L. C., D. A. Wagner, J. Glogowski, P. L. Skipper, J. S. Wishok, and S. R. Tannenbaum. 1982. Analysis of nitrate, nitrite, and $\left[{ }^{15} \mathrm{~N}\right]$ nitrate in biological fluids. Anal. Biochem. 126:131-138.

20. Shichiri, M., Y. Hirata, T. Nakajima, K. Ando, T. Imai, M. Yanagizawa, T. Masaki, and F. Marumo. 1991. Endothelin is an autocrine/paracrine growth factor for human cancer cell lines. J. Clin. Invest. 87:1867-1871.

21. Grynkiewicz, G., M. Poenie, and R. Y. Tsien. 1985. A generation of $\mathrm{Ca}^{2+}$ indicators with greatly improved fluorescence properties. J. Biol. Chem. 260:3440-3450.

22. Yokokawa, K., M. Kohno, K. Yasunari, K. Murakwa, and T. Takeda. 1991. Endothelin-3 regulates endothelin-1 production in cultured human endothelial cells. Hypertension (Dallas). 18:304-315.

23. Devesly, P., P. E. Philips, A. Johns, G. Rubanyi, and L. H. Parker-Botelho. 1990. Receptor kinetics differ for endothelin-1 and endothelin-2 binding to Swiss 3T3 fibroblasts. Biochem. Biophys. Res. Commun. 172:126-134.

24. Fujitani, Y., K. Oda, M. Takimoto, T. Inui, T. Okada, and Y. Urade. 1992. Autocrine receptors for endothelins in the primary culture of endothelial cells of human umbilical vein. FEBS (Fed. Eur. Biochem. Soc.) Lett. 298:79-83.

25. Sakurai, T., M. Yanagisawa, and T. Masaki. 1992. Molecular characterization of endothelin receptors. Trends Pharmacol. Sci. 13:103-108.

26. Sakamoto, A., M. Yanagisawa, T. Sakurai, Y. Takuwa, H. Yanagisawa, and T. Masaki. 1991. Cloning and functional expression of human cDNA for the $\mathrm{ET}_{\mathrm{B}}$ endothelin receptor. Biochem. Biophys. Res. Commun. 178:656-663.

27. Badr, K. F., K. A. Munger, M. Sugiura, R. M. Snajdar, M. Schwartzberg, and T. Inagami. 1989. High and low affinity binding sites for endothelin on cultured rat glomerular mesangial cells. Biochem. Biophys. Res. Commun. 161:776-781.

28. Flemming, J. W., P. L. Wisher, and A. M. Watanabe. 1992. Signal transduction by G-proteins in cardiac tissues. Circulation. 85:420-433.

29. Takuwa, Y., Y. Kasuya, N. Takuwa, M. Kudo, M. Yanagisawa, K. Goto, T. Masaki, and K. Yamashita. 1990. Endothelin receptor is coupled to phospholipase $C$ via a pertussis toxin-insensitive guanine nucleotide-binding regulatory protein in vascular smooth muscle cells. J. Clin. Invest. 85:653-658.

30. Moncada, S., R. M. J. Palmer, and E. A. Higgo. 1989. Biosynthesis of nitric oxide from $L$-arginine: a pathway for the regulation of cell function and communication. Biochem. Pharmacol. 38:1709-1735.

31. Bredt, D. S., P. M. Hwang, C. E. Glatt, C. Lowenstein, R. R. Read, and S. H. Snyder. 1991. Cloned and expressed nitric oxide synthase structurally resembles cytochrome P-450 reductase. Nature (Lond.). 351:714-718.

32. Xie, Q.-W., H. J. Cho, T. Calaycay, R. A. Mumford, K. M. Swiderek, T. D. Lee, A. Ding, T. Troso, and C. Nathan. 1992. Cloning and characterization of inducible nitric oxide synthase from mouse macrophages. Science (Wash. $D C)$. 256:225-228.

33. Lamas, S., R. A. Marsden, G. K. Li, P. Tempst, and T. Michel. 1992. Endothelial nitric oxide synthase: a molecular cloning and characterization of a distinct constitutive enzyme isoform. Proc. Natl. Acad. Sci. USA. 89:6348-6352.

34. Förstermann, U., J. S. Pollock, H. H. H. W. Schmidt, M. Haller, and F. Murad. 1991. Calmodulin-dependent endothelium-derived relaxing factor: nitric oxide synthase activity is present in the particulate and cytosolic fractions of bovine aortic endothelial cells. Proc. Natl. Acad. Sci. USA. 88:1788-1792. 